Volume: 14 Issue: 1 Year: 2017

\title{
Effect of blended learning to academic achievement
}

\author{
Veysel Karani Ceylan ${ }^{1}$ \\ Ayşe Elitok Kesici ${ }^{2}$
}

\begin{abstract}
In this study, the effects of blended learning on the middle school students' academic achievement level and product evaluation scores were investigated. Blended learning provides more effective learning outcome gains through enriching todays' developing Web Technologies with learning environments. This study was carried out with a total of 53 students enrolled in the experimental group and control group in the $6^{\text {th }}$ grade classrooms during the 2014/2015 school year in a middle school in southwest part of Turkey. The intervention lasted 7 weeks. During the seven weeks, the unit of "problem solving, computer programming and development of Software product", covered in Educational technologies and Software course, is taught through blended learning environment. The experimental group was taught using blended learning environment which supported with enriched web technologies (such as video-conference, Learning Management System, Discussion blogs, etc.). Whereas the experimental group was given access to all these enriched contents that are presented to the control group only during the classroom environment through present teaching methods.

The design of the study includes quantitative method. We collected quantitative data such as academic achievement test and product evaluation scale. Academic achievement test and product evaluation scale were used as quantitative data collection sources. Quantitative data was collected through the evaluation of students' projects that they developed during the process of the study and the academic achievement tests. During the data analysis phase, independent t-test, frequency and ANOVA tests were used. As a result of this study, it is concluded that blended learning environment had generated a significant difference in students' academic achievement on behalf of experimental group. Implications of the study for the educational environments were discussed.
\end{abstract}

Keywords: Blended Learning, Flipped Classroom, Coding for Kids, Instruction Method, Computational Thinking

\section{Introduction}

In 21 st century, today's students represent the first generation to grow up with new technologies and are considered as the Z-generation digital natives. They spend their entire lives surrounded by and using computers, videogames, digital music players, video cams, cell phones, and all the other toys and tools of the digital age. Today's average college graduates spend less than 5,000 hours of their lives reading, but over 10,000 hours playing video games (not to mention 20,000 hours watching TV) (Prensky, 2001). Computer games, email, the Internet, cell phones and instant messaging are integral parts of their lives. Under these circumstances, policy makers of schools' systems have to make renovation to educate new generations (Prensky, 2001). Thus, instructors should not ignore new developments in Educational Technologies, which create rich learning

\footnotetext{
${ }^{1}$ Ph.D. Student, veysel232@hotmail.com

2 Asisst. Prof. Dr., Aydin Adnan Menderes University, Faculty of Education, Curriculun and Instruction Department, aelitok@adu.edu.tr
} 
environments. Also, instructors should include digital materials to their learning environments so that more sharing and accessibility will be possible with the Z-generation students, who has new skills and interests in different instructional materials.

According to International Computer and Information Literacy Study (ICIS) report, digital literacy is defined as "an individual's ability to use computers to investigate, create and communicate in order to participate effectively at home, at school, in the workplace and in society" (Fraillon et al, 2013, p. 17). However, in Turkey, this definition is misunderstood when considering the digital literacy capabilities and and skills of Z-generation by the adolescents. Especially spending time on the digital games, downloading applications, or performing simple plug and play hardwares are considered as digital literacy skills, however these are misunderstood skills according to the ICIS report. Particularly, Z-generation should gain new skills related to digital literacy such as algorithmic thinking, problem solving, computer coding and computational thinking.

E-learning environments pave the way for instructional innovations for new generations and make individuals equipped with technologic devices and softwares which provide ubiquitous learning environment. Rich educational environments that contain mobile devices, web platforms and instructional softwares initiate a new period in education using e-learning environments. (Horton, 2002). Those environments will also help students gain digital literacy, digital ethic and selfregulatory proficiencies through using computers. When developing web 2.0 technologies and Information-Computer Technologies (ICT), instructors can use new techniques and methodologies, which pave the way for ubiquitous learning environments and allow practicing elearning tools. One of these methodologies is blended learning that is defined as a computermediated instructional strategy that leverages technology and focuses on the student-teacher relationship to enhance independence, engagement, and achievement. This student-centered, teacher-facilitated strategy includes online and experiential components to strengthen classroom learning. In blended instruction, blending not only includes technology but authentic experiences as well (LaBanca et al, 2013).

Last decade, there have been studies of Nellman (2008), Bliuc (2011) and Suda (2014), which examined academic achievement and satisfaction levels of students, as well views about learning environments have increased seriously. However, most of these investigations were carried out in the higher education degree. There were not enough studies in the K-12 level and in the field of computer programming. Thus, this study aims to fill this gap by investigating the effects of blended learning on academic achievement in the $6^{\text {th }}$ grade classrooms. Besides, the importance of Computer Programming and Creating Software Product unit in the schools has been increasing day by day.

\subsection{Computational Thinking and Scratch Programming}

Computational thinking takes an approach to solving problems, designing systems and understanding human behaviour using concepts fundamental to computing algorithm (Wing, 2008). It can only be considered as computer programming skill, but it's involved in all areas such as mathematics, science and geography. Also, Bundy (2007) asserts that computational thinking influences research in nearly all disciplines, both in the sciences and the humanities. Computational thinking is a kind of analytical thinking and problem solving skill in different areas (Barr \& Stephenson, 2011). Computational thinking should be combined with mathematical thinking in the general ways in which we might approach solving a problem. Computational thinking is similar engineering thinking in the general ways in which we might approach designing and evaluating a large, complex system that operates within the constraints of the real world. Computational thinking is also similar to scientific thinking in certain ways in which we might approach understanding computability, intelligence, the mind and human behaviour (Wing, 2008). 
According to Wing (2008), computational thinking is considered a learning paradigm, consisting of two pillars. One of the pillars is logical deduction, which is similar to problem solving algorithms in the computers in the course of learning activities. Second one is to develop problem solving models such as using Lego blocks. In this process, learners can enhance resolution models and use the suitable coding syntax. In this sense, we can say that computational thinking is a process of problem solving. Its basics lean on the constructivism approach. Computational thinking paradigm was arisen thought the studies conducted in Massachusetts Institute (MIT) in 1973. Computational thinking paradigm targets students' obtaining abstract thought skills rather than teaching computer programming to them (Olabe et al, 2012).

Instructors should help students gain computational thinking via new applications and softwares. In the literature, there are widely used softwares and tools to help students gain the computational thinking. One of the softwares to use for computational thinking includes Scratch. Scratch is a software that can be used to program interactive stories, educational games, and animations. Marques and Marques (2012) pointed out that Scratch allows gaining computational thinking and problem solving skills for the learners. Marques and Marques (2012) described that when the students use a programming language like SCRATCH, they can develop skills as problem solving, analytical thinking and algorithmic thinking, and they soon find problems that they immediately have (feel the need) to solve in order to advance with the project .

Scratch was developed at the MIT Media Lab and is free of charge. Scratch has several characteristics that help new learners in software programming deal with coding and programming. Some of the characteristics include user friendly interface, robotic programming, changing abstract software concepts into concrete concepts, etc. In addition, users can share all the software products with others in the online community (http://scratch.mit.edu). It also provides students to work collaboratively, which is an essential skill required for the 21 st century. As defined by Lamb and Johnson (2010), "In computer software, scratching refers to reusable pieces of code that can easily be combined, shared, and adapted. Students can create stories, games, art, music, animations, and much more" (p.64). Unlike the traditional computer programming languages, Scratch helps all novices focus on what they can do with programming languages (Kim et al, 2012). Because scratch has graphical interface, users do not need to learn coding syntax and conventions. Due to all these characteristic, in this study we also taught students how to use Scratch to develop software products as one of the final assignments of the course.

\subsection{Blended Learning (B-Learning)}

There are a lot of definitions and approaches about how to describe blended learning in the literature. Depending on the learning targets, in the blended learning environments, students learn through face-to-face in class and technology based e-learning environments. The percentage of the in-class and e-learning environments varies. The definition of Blended Learning, used in the American literature for the first-time, concerns both pedagogical approach and learning methods, using media, technology and relations between all of them, bearing in mind what to learn (Gynther, 2005).

Contemporarily, blended learning, known as mixed learning, contains rich learning strategies. According to Harvey and Chris (2001), a blended learning program may consist of one or more program combinations:

combining online and offline learning environments.

combining collaborative and individual learning environments.

combining structure and non-structured learning environments.

combining pedagogical approaches ('e.g. constructivism, behaviourism, cognitivism') to produce an optimal learning outcome with or without instructional technology 
Ceylan, V. K., \& Elitok Kesici, A. (2017). Effect of blended learning to academic achievement. Journal of Human Sciences, 14(1), 308-320. doi:10.14687/jhs.v14i1.4141

Singh and Reed (2001)'s definition of blended learning approaches it as a progress and consider that it should composed of different environments so that instructors are able to get optimized learning outcomes and budget. Therefore, they proposed an elaborated definition and said:

Blended learning focuses on optimizing achievement of learning objectives by applying the "right" learning technologies to match the "right" personal learning style to transfer the "right" skills to the "right" person at the "right" time.

According to their definition, blended learning is a learning program that improves learning effectiveness through extending the access, optimizing the cost of development and time, as well as optimizing learning outcomes.In literature, the most accepted definition includes Osguthorpe and Graham (2003)'s definition that is used to combine face-to-face (F2f) instruction with computermediated instruction in education.

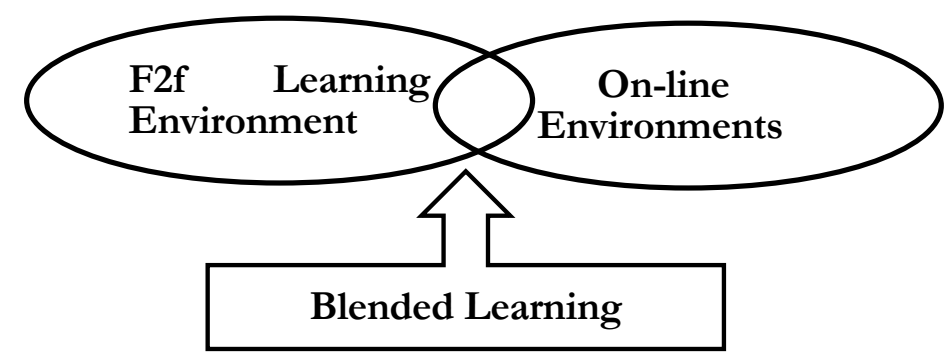

Fig 1. B-Learning's relation between F2f learning and online learning via widespread definition. Source: Çobanoğlu and Ateş (2015; p.92)

Blended learning, is also known as mixed, sandwich, hybrid learning, is a method that conflate traditional learning environments in which led by teachers and technological based e-learning environments (Ayala, 2009; Young, 2002; Valiathan, 2002). During the process of choosing blended learning environments, the educators need to think about the skills that are being taught, learning resources, practicality, time and cost, learners' qualifications and suitable learning theories.

Osguthorpe and Graham (2003) described the following as instructors' reasons to prefer the blended learning environments:

$$
\begin{aligned}
& \cdot \text { Richness of Pedagogy } \\
& \cdot \text { Efficiency of Learning } \\
& \cdot \text { Accessing Knowledge } \\
& \cdot \text { Relevant Cost } \\
& \text { - Easiness of innovation }
\end{aligned}
$$

Essentially, the most important question still includes at what proportion to mix the methods and techniques in order to develop or design effective courses. In order to do that, educators must answer the following questions: - what should be the content of the curriculum, which part of this content should be performed in whether a traditional way or ICT support, and eventually what ICT techniques and tools should be used.

\section{Method}

\subsection{Model}

The design of the study is quantitative methods. We collected quantitative data such as academic achievement tests and product evaluation scale. Quasi-experimental design with pretest - post-test with experimental and control groups were used in this study. For data analysis, we used 
Ceylan, V. K., \& Elitok Kesici, A. (2017). Effect of blended learning to academic achievement. Journal of Human Sciences, 14(1), 308-320. doi:10.14687/jhs.v14i1.4141

independent samples $\mathrm{t}$ test, paired samples t-test, ANOVA, and frequency. Computer program SPSS 21 was used for analyzing the data. In the analysis, it is assumed $\mathrm{p}<0.5$ level of significance.

This study aims to reveal results regarding effectiveness of blended learning in terms of academic achievement, and evaluation product. This study investigates the following research questions:

1. Is there any significant difference between control group and experimental group in respect to achievement academic scores?

2. Is there any significant difference between control group and experimental group in respect to retention of achievement academic scores?

3. Is there any significant difference between control group and experimental group in respect to achievement academic scores in terms of gender?

4. Is there any significant difference between control group and experimental group in respect to retention of achievement academic scores in terms of gender?

5. Is there any significant difference between control group and experimental group in respect to product evaluation scores?

\subsection{Population/Samples/Participants}

The study was conducted at the Computer Technologies and Creating Software Product course. This course has been taught on $6^{\text {th }}$ grade in middle schools in Turkey since 2012. This study was carried out with a total of 53 students enrolled in the experimental group and control group in the $6^{\text {th }}$ grade classrooms during the 2014/2015 educational fiscal-year in a middle school in Turkey. Demographics of the sample provided in Table 1 below.

Table1. Demographic of the Sample in the study

\begin{tabular}{|c|c|c|c|c|c|}
\hline & & & \multicolumn{2}{|c|}{ GENDER } & \multirow[t]{2}{*}{ TOTAL } \\
\hline & & & FEMALE & MALE & \\
\hline \multirow{3}{*}{$\begin{array}{l}\text { 6/A- } \\
\text { Group }\end{array}$} & \multirow{3}{*}{ Experimental } & $f$ & 15 & 10 & 25 \\
\hline & & $\%$ & 60,0 & 40,0 & 100,0 \\
\hline & & $\%$ Total & 28,3 & 18,9 & 47,2 \\
\hline \multirow{3}{*}{\multicolumn{2}{|c|}{ 6/B- Control Group }} & $f$ & 13 & 15 & 28 \\
\hline & & $\%$ & 46,4 & 53,6 & 100,0 \\
\hline & & $\%$ Total & 24,5 & 28,3 & 52,8 \\
\hline \multirow{2}{*}{\multicolumn{2}{|c|}{ Total }} & $f$ & 28 & 25 & 53 \\
\hline & & $\%$ & 52,8 & 47,2 & 100,0 \\
\hline
\end{tabular}

\subsection{Limitations and Study Continuum}

The following steps were performed on this study continuum:

1. To assign control and experimental groups, we considered classrooms' previous academic achievements grades. The experimental and control groups were assigned considering these academic achievement and the individual differences were neglected. Thus, Class 6/A was assigned as the experimental group, and Class $6 / \mathrm{B}$ as the control group.

2. A powerpoint on "Blended Learning" was presented to the students at the beginning of the study. The students in the experimental group were informed about the way this instruction method would be used. Also, beyazpano.com was used as a Learning Management System (LMS). We introduced beyazpano.com to the students in experimental group, and did their registration to LMS. Beyazpano.com provided us to develop and share homework assignments, quizes and exams, 
ideas, videos, and pictures on their clasroom profile. Experimental group spent time for following course one hour in their homes via using internet. There were carried out some applications such as youtube canal, google hangout, scratch forum and beyazpano.com in order to guide to experimental group and present content of course in online environments. In school F2f environment, we developed home assignments and evaluated them. Also all groups used computer labs in that they completed all assignments and developed their software products.

3. While we carried out face-to-face traditional approach for two hours for control group, we used the blended learning approach for one hour F2f and one hour online instruction in a week for the experimental group.

4. The duration of the intervention lasted for two hours during the seven-week continuum.

5. After they completed the course, four weeks later we carried out a retention test, which is the same academic test to both the control and the experimental groups.

\subsection{Data Collecting Tools}

Data were collected using academic achievement test and product evaluation scale. We explained detail information about these in following.

\subsubsection{Academic achievement test}

Academic achievement test was developed in order to measure the students' achievement in the unit of Problem Solving, Computer Programming and Development of Software Product in the $6^{\text {th }}$ grade Computer Technologies and Creating Software Product course. The academic achievement test was developed using the Bloom's cognitive domain steps including Knowledge, Comprehension, Application, Analysis, Evaluation and Synthesis. Even though we think that the test was appropriate to skills developed based on Bloom's cognitive domain steps, academic achievement test cannot assess all the skills in the course especially the skills required in the application and its above step. That's why we included the final product assignment to assess the skills gained through the application, synthesis and evaluation step in our course content. The academic achievement test was prepared in line with the gains of the subject stated in the Training Program. All gains related to topic content should be surveyed with at least one question in academic achievement test. Test developed to investigate each of the behaviors set at the level of knowledge, understanding and practice related to these gains. For the validity of the questionnaires prepared as a draft, the subject area experts (1 faculty member, 2 researchers, 2 researchers, 4 experienced informatics teachers), education program and teaching department from the department of Computer and Instructional Technology Education Officials) were consulted. After the corrections made in line with the opinions and recommendations of the subject experts, a final 58-item multiple-choice test was prepared by giving the final form to the test. The questions in the test consisted of 4 multiple choice questions. There were also questions in the negative root that have been tried to pay attention to the fact that the root of the question was positive, and the negative situation was indicated underlined. The preliminary application of the Academic achievement test was conducted on a total of 68 students on grade 7 of a Private Middle School in Milas.Item discrimination and difficulty values and internal consistency of the test were calculated using the SPSS v21 (Statistical Package for the Social Science) program. Arithmetic mean, standard deviation, item discrimination power, item difficulty index, test reliability coefficient were calculated and item and test statistics were analyzed.According to substance discrimination indices, the removal of 15 questions from the test and test has turned into a 42-question test.

\section{Product evaluation scale}

Unit of computer programming and creating software product has senior skills which are knowledge, comprehension, application, analyse, evaluation and syntheses level of cognitive domain. In this sense; scale should contain all gains that on the subject of computer programming 

14(1), 308-320. doi:10.14687/jhs.v14i1.4141

for the content validity. Product evaluation scale was developed in order to measure the skills required in the application, evaluation and syntheses level of cognitive domain by four computer instructors, who have experience in the field of computer programming and coding. After we developed the product evaluation scale, we used it to evaluate 68 six-grade students' products in a pilot school in order to test our scale. We found out that product evaluation scale contains all the gains included in the subject of computer programming, ensuring the content validity of the scale. After we test our scale in a pilot school, we used it to evaluate a total of 53 students' products in both control and experimental group in our study. Two computer instructors, one of them is the first author, evaluated the students' products using the product evaluation scale, then we calculated the mean of evaluators' points.

\subsection{The Significance of the Study}

Learning computer code is hard issue for new pupils (Boulay, 1989). So we can say that computer programming is the most substantial and crucial issue in computer science. As we overcome this problem, we used varied methods that named blended learning which is used new technologic ways and independence old methods in instructions. Also, in literature we couldn't see anymore examines about blended learning in computer programming courses. In addition to, blended learning model which is obtained from this study and it will practice other diciplines such as Geography, Maths, Social Sciences.

\section{Conclusions}

The findings are organized around each research question. We provide the details of the findings below.

\section{Is there any significant difference between control group and experimental group in respect to academic achievement scores?}

We used blended teaching methods to the experimental group and common curriculum with present teaching methods to the control group. We investigated the the difference between control group and experimental group in respect to their academic achievement score. We carried out twofactor analysis of variance for repeated measurements on a single factor using ANOVA test. The results of test are given in Table 2 below.

Table 2. Comparison of Experimental and Control groups' results of pre-test and post-test in terms of academic achievement $(p<, 05)$

\begin{tabular}{lcccccc}
\hline \multicolumn{1}{c}{$\begin{array}{c}\text { Source of } \\
\text { Variance }\end{array}$} & $\begin{array}{c}\text { Sum of } \\
\text { squares }\end{array}$ & df & $\begin{array}{c}\text { Mean } \\
\text { Sq. }\end{array}$ & f & p & Sig. \\
\hline $\begin{array}{l}\text { Between groups } \\
\begin{array}{l}\text { Experimental and } \\
\text { Control groups }\end{array}\end{array}$ & 1360,54 & 1 & 1360,54 & 8,21 &, 006 &, 139 \\
\hline Error & 8449,83 & 51 & 165,68 & & & \\
\hline In Groups & & & & & & \\
\hline $\begin{array}{l}\text { Measure (pretest- } \\
\text { posttest) }\end{array}$ & 11363,27 & 1 & 11363,27 & 202,89 &, 000 &, 799 \\
\hline Group* Measure & 1870,99 & 1 & 1870,99 & 33,46 &, 000 &, 396 \\
\hline Error & 2856,37 & 51 & 56,01 & & & \\
\hline Total & 51802 & 52 & & & & \\
\hline
\end{tabular}


Ceylan, V. K., \& Elitok Kesici, A. (2017). Effect of blended learning to academic achievement. Journal of Human Sciences, 14(1), 308-320. doi:10.14687/jhs.v14i1.4141

In Table 2, there was a significant difference between control group studying with the Ministry of Education program through a present teaching's setting and experimental group studying in the blended learning environment in order to teach subjects of Coding and Programming through beyazpano.com via distance learning in terms of pre-test and post-test $\left(\mathrm{F}_{(1,51)}=8,21\right.$, $\mathrm{p}<, 05)$. According to all groups' scores of pre-test and post-test, there was a significant difference between scores of pre-test and post-test. $\left(\mathrm{F}_{(1 ; 51)}=8,21, \mathrm{p}<, 05\right)$. In addition; there were asserted that preliminary tests showed that students in the experimental group compared to the last test measuring the difference between the academic achievement scores $\left(\mathrm{F}_{(1,51)}=202.89 ; \mathrm{p}<.05\right)$. The experimental group students' pretest and post-test were found to be significantly different from the control group students' pre-test and post-test scores in academic achievement changes. $\left(F_{(1,51)}=\right.$ $33.46, \mathrm{p}<.05)$.

\section{Is there any significant difference between control group and experimental group in respect to retention of achievement academic scores?}

After 5 weeks upon completion of the study, we carried out a retention academic test in order to determine retention in control and experimental group through applying independent sample $\mathrm{t}$ test.

Table 3. Compare of Experimental and Control groups' in terms of Retention Test $(p<, 05)$

\begin{tabular}{llllllll}
\hline \multirow{2}{*}{ Group } & \multicolumn{7}{c}{ Levene test } \\
\cline { 2 - 7 } & $\mathbf{n}$ & $\mathbf{x}$ & ss & $\boldsymbol{f}$ & $\boldsymbol{p}$ & $\boldsymbol{t}$ & $\boldsymbol{p}$ \\
\hline Experimental & 25 & 81,87 & 8,54 & \multirow{2}{*}{1,73} & \multirow{2}{*}{194} & 4,08 & \multirow{2}{*}{000} \\
\hline Control & 28 & 68,3 & 14,2 & & & & \\
\hline Total & 53 & & & & & & \\
\hline
\end{tabular}

Table 3 indicates that control group has average 68.3 score of retention test score, whereas experimental group has 81,87 score average of retention test score. There were a significant difference between groups in favour of the experimental group in terms of scores of retention test . Experimental group's test scores are greater than control group's test scores. The effect size calculated for the group variable is determined as $\eta^{2}=, 24$. The Cohen $d$ value is determined as 1.12 . According to these values, it's calculated as $24 \%$ effect of Blended learning Environment on scores of retention test. So, calculated values show that the effect size is moderate effect for the Blended Learning Environment variable.

\section{Is there any significant difference between control group and experimental group in respect to achievement academic scores in terms of gender?}

To determine whether there are significant differences between groups in different gender groups in respect to academic achievement score we applied ANOVA test and Scheffe test. The test results in Table 4 shown whether there are significant differences between groups in terms of gender.

Table 4. Compare post-test scores in terms of gender $(p<, 05)$

\begin{tabular}{|c|c|c|c|c|c|c|}
\hline \multirow{2}{*}{ Variable } & \multirow{2}{*}{$\begin{array}{c}\text { Source } \\
\text { of } \\
\text { Varience }\end{array}$} & \multirow{2}{*}{$\begin{array}{l}\text { Sum of } \\
\text { squares }\end{array}$} & \multirow{2}{*}{$d f$} & \multirow{2}{*}{ Mean Sq. } & \multirow[b]{2}{*}{ f } & \multirow[b]{2}{*}{$p$} \\
\hline & & & & & & \\
\hline \multirow{3}{*}{ Gender } & $\begin{array}{l}\text { Between } \\
\text { Groups }\end{array}$ & 3764,399 & 3 & 1254,800 & \multirow{2}{*}{8,779} & \multirow{2}{*}{,000 } \\
\hline & $\begin{array}{l}\text { In } \\
\text { Groups }\end{array}$ & 7003,526 & 49 & 142,929 & & \\
\hline & Total & 10767,925 & 52 & & & \\
\hline
\end{tabular}


Ceylan, V. K., \& Elitok Kesici, A. (2017). Effect of blended learning to academic achievement. Journal of Human Sciences, 14(1), 308-320. doi:10.14687/jhs.v14i1.4141

We carried out ANOVA and Scheffe test in order to determine significant difference in groups regarding gender. Table 4 indicates that there is no significant difference in post-test between female and male in experimental group. But, there is a significant difference in post-test between females having average score of 68,84 and males having average score of 60 in the control group. We also carried out Scheffe Test in order to determine what size the difference is between groups. In consequence of this test, we found that female students in the control group turned out more successful than male students in the control group. $\left(\mathrm{F}\left({ }_{4,8}\right)=0.02 ; p<0.05\right)$. We calculated eta size effect as ,59. We found that there is a significant difference due to $\eta>0,5$.

\section{Is there any significant difference between control group and experimental group in respect to retention achievement academic score in terms of gender?}

We used independent sample $t$ test in order to determine if there is any significant difference between control group and experimental group in respect to retention achievement academic score in terms of gender. We showed retention scores and test results in terms of gender in table 5 below..

Table 5 Comparing retention test scores of groups in term of gender $(p<, 05)$

\begin{tabular}{|c|c|c|c|c|c|c|c|c|}
\hline \multirow{2}{*}{ Experimental Group } & & & \multicolumn{6}{|c|}{ Levene test } \\
\hline & Gender & $\mathbf{n}$ & $\mathbf{x}$ & ss & f & $\mathrm{p}$ & $t$ & $p$ \\
\hline \multirow{2}{*}{ Retention } & Male & 10 & 78,75 & 8,68 & \multirow{2}{*}{,09 } & \multirow{2}{*}{, 767} & \multirow{2}{*}{1,26} & \multirow{2}{*}{,22 } \\
\hline & Female & 15 & 83,16 & 8,52 & & & & \\
\hline \multicolumn{9}{|l|}{ Control Group } \\
\hline \multirow[b]{2}{*}{ Retention } & Male & 15 & 62,83 & 15,75 & \multirow[b]{2}{*}{1,17} & \multirow[b]{2}{*}{,288 } & \multirow[b]{2}{*}{2,36} & \multirow[b]{2}{*}{,026 } \\
\hline & Female & 13 & 74,61 & 9.17 & & & & \\
\hline
\end{tabular}

We found that there is a significant difference in control group in terms of gender in the favour of female students $\left(t_{(28)}=2,36\right.$ ve $\left.p=, 026\right)$. But we didn't see the same results for the experimental group. We found that there is no difference in experimental group for the retention test score in terms of gender $t_{(25)}=1,26, p=, 22$. Moreover, it was made out a deduction that there was a significant difference in control group regarding to gender female students' favour and signifacant's size effect as cohen $d$ was calculated ,75 and eta square $\left(\eta^{2}\right)$ was found as 0,17 . Therefore, variance effect size was founded as $17 \%$.

\section{Is there any significant difference between control group and experimental group in respect to product evaluation scores?}

At the end of the unit, all groups developed software products using scratch programming. Two computer teachers independently evaluated products using the product evaluation scale. The final assessment scores was appointed their evaluations' arithmetic averages. We used independent t-test using those points and the results are shown in the following Table 6.

Table.6. Comparing Product Evaluation Scores of group of experimental and control. $(p<, 05)$

\begin{tabular}{|c|c|c|c|c|c|c|c|}
\hline \multirow{2}{*}{ Groups } & \multicolumn{7}{|c|}{ Levene test } \\
\hline & $\mathrm{n}$ & $\mathbf{x}$ & ss & f & $\mathrm{p}$ & $\mathbf{t}$ & $\mathrm{p}$ \\
\hline Experimental & 25 & 84,48 & 10,27 & 0.01 & 076 & 265 & 011 \\
\hline Control & 28 & 76,6 & 11,22 & 0,01 & & 2,00 & ,011 \\
\hline Total & 53 & & & & & & \\
\hline
\end{tabular}


In order to assess whether there is a significant difference between product development grade averages of the experimental group and the control group, we used independent sample tests. We found that there is a significant difference between groups in favor of experimental group in terms of product development grade average. $(p<.05)$. The average grade of the experimental group was 84.48 while average grade of the control group was 76.6.

The blended learning environment, the extent of the effect size in the name explains that the effect of the impact on the points evaluation product gained the group and Cohen's d calculated value, effect size - Eta square $\eta 2=0,12$ and Cohen $\mathrm{d}$ is calculated as 0,72 . Regarding to the results of effect size, we retained $12 \%$ of the variance of product evaluation scores that is different from by the blended learning environment. The value of the effect has been found to be at a high level as ,72. According to these results, we concluded that there is a significant difference in favour of experimental group.

\section{1. DISCUSSION}

We found that the experimental group who has studied in blended learning environment is academically more successful than the control group who has studied in present teaching environments. In literature, there has been various studies which have similar findings with our study. Most of those studies also found that blended learning environment increases the academic achievement averages (Sartepeci, 2012; Uluyol \& Karadeniz, 2009; Y1lmaz, 2011; Demirkol, 2012; Usta, 2007; Ilın, 2013; Y1lmaz \& Orhan, 2010; Bağc1, 2012; Robinson, 2004 and Dziuban et al, 2004). However, there has been studies in which there are opposing views about if the blended learning environment increases the academic achievement (Akkoyunlu \& Soylu, 2008; Delialioğlu \&Yıldırım, 2007; Demirer, 2009). Because of findings, there were used academic achievement test and product evaluation scale as data collection tools which was developed by expert and was tested for reliability and validity.

Past studies about blended learning show that qualities and quantities of interaction of blended learning environments directly influenced to academic achievements, experienced, senior learning skills of students (Geçer ve Dağ, 2012; Kuo et al, 2014). Such as Uluyol and Karadeniz (2009), carried out a study blended learning using project based learning, expressed an opinion that participants would be more active course of the study. According to the findings of this study that there is a significant difference in favour of experimental group in terms of creating software product. Product development process, there were made necessary and sufficient routing within each group using beyazpano.com, mail, skype vs.. End of the study, the experimental group have uploaded their projects beyazpano.com, whereas the control group students perform their products in the classroom by making presentations face to face.

Considering that there is a significant difference between the study groups in terms of gender groups in their academic achievement, there was no difference between girls and boys in the experimental group, but the groups were found to be significant differences in favor of girls between groups of boys and girls in the control group. The same result is seen in study of Demirkol (2012) and Uğur (2007). As the cause of this difference, female students of control group was also found to be higher than in the lecture notes of male students in other subjects. Male students were observed to use the Internet for games and entertainment rather than working and trying for programming in the laboratory during the study.

Retention test scores were found to be significant differences in favor of experimental group. Ünsal's work (2006) depending on the gender differences not being seen between in the control group and experimental group, although the control group in the study showed a significant difference in favor of girls between the gender in the retention test. At the study called blended learning and online learning Academic Achievement and Satisfaction Impact Media, Usta and Mahiroğlu (2015) reached the conclusion that the blended learning training students more 
successful academically than learning environment for students only in the field of online education.

While web based learning environment provides flexible place and management time for instructors, face to face learning (f2f) environments can provide social interactivity which enable better learning activities for students (Abate, 2004). During this study, there were used both web based learning environments and $\mathrm{f} 2 \mathrm{f}$ learning environments. Students can get access to course's econtents in any place and any time period via using internet. There were used beyazpano.com as learning management system enables immediately chat, discussion boards by participants actively in course of study. Also Kirişçioğlu (2007) investigated and asserted that blended learning environments increase communication skills of participants. So, all of them could make contact with their instructors by means of blended learning provides rich communication channels such as chatrooms, social media, discusision forms, web 2.0 tools.

\subsection{IMPLICATIONS/ SUGGESTIONS}

There are offered suggestions for teachers or instructors who will applied to blended learning environments with findings were obtained from this study in the sense of leading the way of them.

1. In this study, it was carried out a blended learning environment mixed at the rate of $50 \%-50 \%$ ( $50 \%$ face to face, $50 \%$ on-line). Various blended learning environments can be conducted as mixed ratios. Furthermore, there can be benefitted from diversified strategies and methods such as collaboration methods, project based learning vs..

2. It could be developed mobile version of scratch programming which was used as visual programming tool in this study. So, participants could spend their time with scratch much more.

3. The studies will be held on future can be carried out that there would be enrichment web materials which would be produced by professional content developer team.

4. This study has offered a blended learning environment by using traditional learning environment and online learning environment together. Not only did computer science class used this environment, but also other classes such as Math, Science, Social Science could carry out.

\section{REFERENCES}

Abate, L. M. (2004). Blended model in the elementary classroom. Teach Learning. (11.12.2014), http:/ / www.techlearning.com/story/show/Article/jhtml?articleID $=45200032$.

Akkoyunlu, B. ve Soylu, M., Y. (2008). A Study of Student's Perceptions in a Blended Learning Environment Based on Different Learning Styles. Educational Technology \& Society, 11 (1), 183-193.

Ateş, A. ve Çobanoğlu, A. (2013). Harmanlanmış öğrenmenin öğrencilerin erişilerine, alg1ladıkları bilişsel esneklik düzeylerine ve öz düzenleyici öğrenme becerilerine etkisi. (Unpublished Doctorte Thesis). İzmir Ege University, Social Science Institute.

Ayala, J. (2009). Blended Learning As A New Approach To Social Work Education. Journal of Social Work Education Volume 45, Issue 2.

Bağc1, H. (2012), Harmanlanmış Öğrenme Ortamında Denetim Odağına Göre Uyarlanmış 5e Öğrenme Modelinin Öğrencilerin Akademik Başarısına Ve Memnuniyetine Etkisi. Doktora Teri, Gazi Üniversitesi Ë̆itim Bilimleri Enstitüsü Ĕ̈itim Bilimleri Anabilim Dah

Barr, V., ve Stephenson C., (2011). Bringing Computational Thinking to K-12: What is Involved and What is the Role of the Computer Science Education Community?. ACM Inroads, 2(1), 48-54. 
Ceylan, V. K., \& Elitok Kesici, A. (2017). Effect of blended learning to academic achievement. Journal of Human Sciences, 14(1), 308-320. doi:10.14687/jhs.v14i1.4141

Boulay, B. (1989). Some difficulties of learning to program. In E. Soloway and J.C. Spohrer (eds.), Studying the novice programmer. Hillsdale, N.J.L. Erlbaum Associates.

Bundy, A. (2007). Computational thinking is pervasive. J. Scient. Pract. Comput. 1,67-69.

Çobanoğlu, A. ve Altun, E. (2015). Geleneksel öğretimden Harmanlanmış Öğrenme Temelli Öğretime, Eğitim Teknolojileri Okumalar s.89-107, Ankara

Delialioğlu, O. ve Yıldırım, Z. (2007). Students' Perceptions on Eff ective Dimensions of Interactive Learning in a Blended Learning Environment. Educational Technology \& Society, 10 (2), 133-146.

Demirer, V. (2009). Eğitim materyali geliştirilmesinde karma Öğrenme yaklaşımının akademik başar1, Bilgi transferi, tutum ve öz-yeterlik Alg1sına etkisi. Yüksek Lisans Teri. Selçuk Üniversitesi Sosyal Bilimler Enstitïsü Eğitim Bilimleri Anabilim Dah Eğitim Programlar ve Ögretimi Bilim Daln

Demirkol, M. (2012). Ortaöğretim Kurumlarında Harmanlanmış Öğrenme Ortamının Akademik Başarıya ve Öğrenci Tutumlarına Etkisi. Yüksek Lisans Tę̧, Furat Üniversitesi Eğitim Bilimleri Enstitïsü Ë̆itim Programlarn ve Ögrretim Anabilim Dah, Elazı ̆̆.

Dziuban, C. D., Hartman, J.L. ve Moskal, P. D. (2004). Blended Learning. Educase Center for Applied Research, ECAR. Issue 7.

Fraillon, J., Ainley, J., Schulz, W. ve Friedman, T. (2013). Preparing for Life in a Digital Age. The IE A International Computer and Information Literacy Study International Report, Australian Council for Educational Research (ACER), Melbourne, Australia

Geçer, A. ve Dă̆, F. (2012). Bir Harmanlanmış Öğrenme Tecrübesi, Kuram ve Uygulamada Ĕgitim Bilimleri. Educational Sciences: Theory \& Practice - 12(1), s. 425-442

Gynther, K. (2005). Blended learning. Unge Pxdagoger, København.

Harvey, S. ve Chris, R.(2001). A White Paper: Achieving Success with Blended Learning. 21.01.2015. bttp:/ / wnw.centra.com/ download/wbitepapers/blendedlearning.pdf.

Horton, W. (2002). Designing web-based training. NY: Wiley

Ilın, G. (2013 ). Moodle: A Way For Blending Vle And Face-To-Face Instruction In The Elt Context. The Turkish Online Journal of Educational Technology October 2013, volume 12 issue 4.

International Society for Technology in Education. (2012). National Educational Technology Standards and Performance Indicators for All Teachers. Son 05.12.2014, http://cnets.iste.org/teachers/t_stands.html.

Johnson, J. (2002). Reflections on Teaching a large enrollment course using a hybrid format. Teaching with Technology Today, 8(6) http://www.vwsa.edu/ttt/articles/jjohnson.htm

Kim, H., Choi, H., Han, J., So, H. (2012). Enhancing teachers' ICT capacity for the 21st century learning environment: three cases of teacher education in Korea. Australasian Journal of Educational Technology (AJET), 28(6).

Kirişçioğlu, S. ve Başdaş, E. (2007). Moodle Platformu İle İnternet Destekli Eğitim ve Uygulama Örneği. I. Uluslararası Bilgisayar ve Ögretim Teknolojileri Sempozyumu, Kongre Özetler Kitabı: 181. Çanakkale.

Kuo, Y., Belland, B. R., Schroder, K. E., \& Walker, A. E. (2014). K-12 teachers' perceptions of and their satisfaction with interaction type in blended learning environments. Distance Education, 35(3), 360. doi:10.1080/01587919.2015.955265

LaBanca, F., Worwood, M., Schauss, S., LaSala, J., \& Donn, J. (2013). Blended instruction: Exploring studentcentered pedagogical strategies to promote a technology-enhanced learning environment. CT: Education Connection, Litchfield

Lamb, A., \& Johnson, L. (2010). Bring back the joy: Creative teaching, learning, and librarianship. Teacher Librarian, 38(2), 61-66.

Ornelas Marques, F., Marques, M.T. (2012). No problem? No research, little learning ... big problem!. Systemics, Cybernetics and Informatics, 10(3), 60-62 
Ceylan, V. K., \& Elitok Kesici, A. (2017). Effect of blended learning to academic achievement. Journal of Human Sciences, 14(1), 308-320. doi:10.14687/jhs.v14i1.4141

Nellman, S. (2008). A Formatıve Evaluation Of A High School Blended Learning Biology Course. Doktora Tezi .A Dissertation Presented To The Faculty Of The Rossier School Of Education University Of Southern California, 2008, California.

Olabe, J.C. Olabe, M.A., Basogain X., Castaño, C. ve Maiz I., (2012) . Programming and Robotics with Scratch in Primary Education. Education in a technological World. Spain.

Ornelas Marques, F., Marques, M.T. (2012). No problem? No research, little learning ... big problem!. Systemics, Cybernetics and Informatics, 10(3), 60-62.

Osguthorpe, R. T., \& Graham, C. R. (2003). Blended learning systems: Definitions and directions. Quarterly Review of Distance Education, 4(3), 227-234

Prensky, M. (2001). Digital natives, digital immigrants. On the Horizon MCB University Press, Vol. 9 No. 5. October 2001.

Robinson, R. A. (2004). Selected Faculty Experiences in Designing and Teaching Blended Learning Courses at Brigham Young University. ETD collection for University of Nebraska Lincoln. UMI Number: 3147153. Scratch.mit.edu. Retrieved from https://scratch.mit.edu/about last access 12.05.2015

Sarıtepeci, M. (2012). İlköğretim 7. sınıf sosyal bilgiler dersinde harmanlanmış öğrenme ortamlarının öğrencilerin derse katılımına, akademik başarısına, derse karşı tutumuna ve motivasyonuna etkisi. Yüksek Lisans Tezi. Gazi Üniversitesi Eğitim Bilimleri Enstitüsü. Bilgisayar ve Öğretim Teknolojileri Eğitimi Anabilim Dalı . Ankara.

Suda, J., Sterling, M., Guirguis, B. ve Mathur K. (2014). Student perception and academic performance after implementation of a blended learning approach to a drug information and literature evaluation course. Currents in Pharmacy Teaching and Learning. Cilt 6, Say1 3, Mayis-Haziran 2014, s. 367-372

Singh, H. ve Reed, C. (2001). A White Paper: Achieving Success with Blended Learning .ASTD State of the Industry Report, American Society for Training \& Development, March 2001

Wing, J. (2008). Computational Thinking. Commun. ACM 49, 3, s. 33-35.

Uğur, B. (2007). Öğrencilerin Karma Öğrenme Yöntemine Ve Yöntemin Uygulanmasına Yönelik Görüşlerinin Başarı, Cinsiyet ve Öğrenme Stilleri Açısından İncelenmesi .Yülksek Lisans Teŗ, Hacettepe Üniversitesi Fen Bilimleri Enstitüsü, Ankara.

Uluyol, Ç. ve Karadeniz, Ş. (2009). Bir Harmanlanmış Öğrenme Ortamı Örneği: Öğrenci Başarısı ve Görüşleri. Yü̊üncü Yll Üniversitesi, Eğitim Fakültesi Dergisi. Haziran 2009. Cilt:V1, Say1:I, 60-84

Usta, E., Mahiroğlu, A. (2015). Harmanlanmış Öğrenme ve Çevrimiçi Öğrenme Ortamlarının Akademik Başar1 ve Doyuma Etkisi. Ahi Evran Üniversitesi Kırşehir Ë̈itim Fakültesi Dergisi, 9 (2), 1-15. Retrieved from http:/ / dergipark.gov.tr/ aeukefd/ issue/1418/17010

Usta, E. (2007). Harmanlanmış Öğrenme ve Çevrimiçi Öğrenme Ortamlarının Akademik Başarı ve Doyuma Etkisi. Yayınlanmamış Doktora Teæri, Gazi Üniversitesi, Ankara.

Ünsal, H. (2007). Harmanlanmış Öğrenme Etkinliğinin Çoklu Düzeyde Değerlendirilmesi. Doktora Teri, Gazi Üniversitesi, Ankara.

Valiathan, P. (2002). Blended Learning Models. Learning Circuits. 18.02.2015. wnw. learningcircuits.org/2002/ang2002/valiathan. btml

Yılmaz, G. (2011). Karma öğrenme sistemlerinde ulaşılabilir bilgisayar Teknolojilerinin kullanımı. Yüksek Lisans Teq̨i. Anadolu Üniversitesi Eskişehir.

Yilmaz, B. ve Orhan F. (2010). Pre-service english teachers in blended learning environment In respect to their learning approaches. The Turkish Online Journal of Educational Technology. January 2010, volume 9 Issue 1

Young, J.R. (2002). Hybrid Teaching Seeks To End The Divide Between Traditional And Online Instruction. The Chronicles Of Higher Education, A33. 19.05.2015, http://chronicle.com/article/Hybrid-Taching-Seeks-to/18487 